\title{
最近の歯学
}

\section{4. 予防齿科}

\section{自律訓練法と予防歯科学}

束京医科歯科大学歯学部予防歯科学教室 川口陽 子, 志村 則夫

今日, 文化や社会構造の急激な変化に伴って, 母親の 育児管勢や家庭や職場での人間関係にも変化がみられ, 健康な状態でこれらの变化に適応していくことが極めて 困難になりつつある。適応不全病とみられる精神疾患や 成人病の急増がそれを物語っているといえよう。ウ蝕や 歯周疾患も人のライフスタイルと密接な関係があるし, 心因性原因や上述したよらな社会への適応のつまずきが 原因と考えられる口臭や舌痛を主訴とする患者も少なく ない。予防歯科では，このような患者に対して自律訓練 法を試みているので紹介する。

自律訓練法は、ドイッの J. H. Schultz やカナダの W. Luthe ${ }^{1)}$ らによって開発された一種の 自己催眠療法 で，不適応状態に陥った人間が自己を取りもどし，本来 備えている恒常性を最大に発揮できる状態へと導く療法 である。

技法: 静かな部屋の中で椅子に深く腰かけて楽な姿勢 を取る。閉眼して「気持ちがとても落ち着いている」と いら自己暗示に続いてつぎの公式に段階的に入る。

公式 1 . 両手, 両足がけたるる重たい（重感）

2. 両手, 両足がぽかぽかと温かい（温感）

3. 心蔵が静かに規則正しく打っている（心蔵 調整)

4. 呼吸がゆっくり楽にできる（呼吸調整）

5. 胃のあたりが温かい(腹部温感)

6. 額が心地よく涼しい（額部涼感）

これが標準練習であるが，ここで大切なことは，手足 を温かくするのではなく，温かいと感ずる受身的注意集 中をすることである。技法を習得させた後は，少なくと も 1 日に 1 回自宅でこの自律訓練法を行うよう指導して いる。公式 6 までいかなくても, 重感・温感を会得でき るよらになると，恒常性が回復し，より健康的な心身の 状態になり，心因性原因を持つような患者においては， 症状が軽快してくる場合が多い。

当科では，この自律訓練法を患者に指導する際，パ オトレーナーを利用して皮隔温や GSR（皮膚電気抵抗）
を測定して，器械からの信号を患者にフィードバックし ている。図1のAのように, 䋜張状態の改善されない者 むいるが，95名中 66 名の患者 $(69.5 \%)$ は, 訓練の結 果 Bのようなリラックス状態が得られ, 症状の消失や改 善が認められた。

このよらに疾病の治撚を促す過程においてては，心身を リラックスさせることが効果的である。人間が本来備え ている恒常性を最大に発揮できるように務めることが, 口腔の疾病のみならず, 健康の保持增進の上からも重要 と考えられるのである。

\section{文献}

1） W. Luthe：自律訓練法（池見西次郎監修） I II III IV V VI. 東京, 1971, 誠信書房.
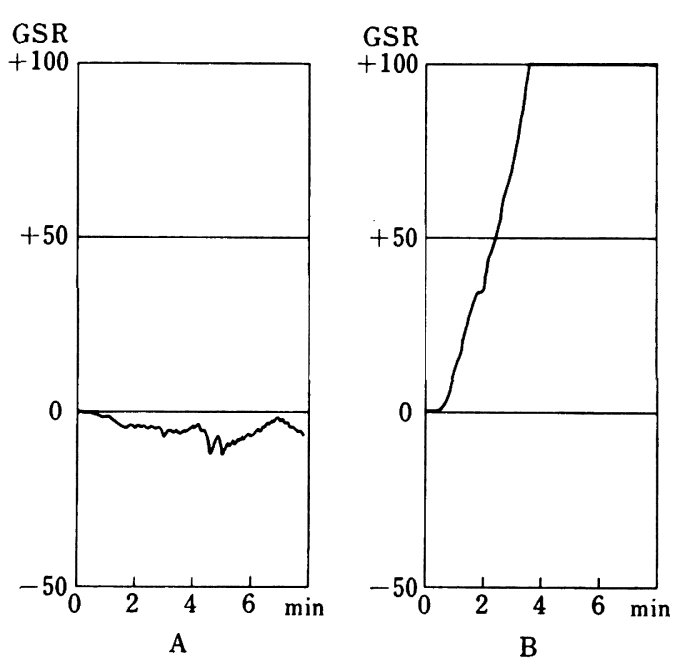

図 1 バイオトレーナーでGSR を測定して自律訓練法 を行った例

A 祭張状態 : GSR 值は変化なしか, 低下する B リラックス状態：GSR 值が経時的に上昇する 